CHUNG-YING CHENG

\title{
OBITUARY OF LIK-KUEN TONG
}

Lik-kuen Tong (Liquan Tang) 唐力權 (1935-2012) was an important Chinese scholar-philosopher rooted in Whitehead and the Chinese philosophy of the Yijing 《易經》 with innovative ideas.

Lik-kuen graduated from New School of Social Research with a Ph.D. specializing on Whitehead in early 1970s. He was also one of a few who took an early interest in the Yijing and saw the common and mutual sharing of concepts of time and reality between Whitehead and the Yijing. Later he published a Chinese book titled Zhouyi yu Huaidehai zhijian 《周易與懷德海之間》. ${ }^{1}$ It is an abstruse book full of new terms that takes a while to be understood. He wrote many articles that were published in the Journal of Chinese Philosophy $(J C P)$. His first article was published in $J C P$, which dealt with the concept of time in Whitehead and the Yijing as early as 1974. His second article was on transcendence of language in Chinese philosophy, which was also published in JCP, and it led to his talk of philosophical silence. I recall his third article was comparing Whitehead and Chinese philosophy at a conference in Colorado in 1979, for which $J C P$ published together with other articles from the same conference.

Lik-kuen often spoke of his idea of gan-tong 感通 (kang-tung in his spelling) in explaining Zhu Xi's view on human mind and its relation to human nature. Since 1990, he explicitly had applied the term gantong in his explanation on the significance of how a gua 卦 came from appropriation in a process of feeling and response. I believe that it was his concern with the process of gan-tong that eventually developed his idea of field-being (changyou 場有). He founded a society to promote the idea and philosophy of field-being, and it no doubt has made an invaluable contribution to contemporary Chinese philosophy.

Lik-kuen joined the International Society for Chinese Philosophy (ISCP) as early as immediately after the society was formed by me. He suggested that we should use the term "international" as an

CHUNG-YING CHENG, Editor-in-Chief, Journal of Chinese Philosophy; Professor, Department of Philosophy, University of Hawaii at Manoa; Visiting Zhiyuan Chair Professor, College of Humanities and Arts, Shanghai Jiaotong University. Specialties: Confucianism and Neo-Confucianism, hermeneutics/onto-hermeneutics, philosophy of language. E-mail: ccheng@hawaii.edu 
epithet. Besides, it was him who organized the first international conference of ISCP in his home university, Fairfield University. He functioned hence as the Secretary of the ISCP, and a few years later, Lik-kuen had served as Chair of the Executive Committee and continued to serve the position until 2001. It is during the last eight years as Chair of the Executive Committee of ISCP that Lik-kuen founded his society for the field-being with an institute.

Under the name of Society for Field Being, Lik-kuen sponsored many meetings and conferences on field-being in China, notably in Xian at Shanxi Normal University. He published several volumes of studies in Chinese philosophy with reference to his philosophy of field being. He also founded a branch of his Institute in Hong Kong where he last dwelled before he passed away.

Lik-kuen had been a supportive colleague as well as a special friend of mine for decades, and I shall remember him warmly and deeply.

JOURNAL OF CHINESE PHILOSOPHY UNIVERSITY OF HAWAII AT MANOA Honolulu, Hawaii

\section{ENDNOTE}

1. Tong Lik-kuen (Tang Liquan) 唐力權, Zhouyi yu Huaidehai zhijian 《周易與懷德海 之間》 (Taipei: Liming Wenhua Shiye Gufen Youxian Gongsi, 1989). 